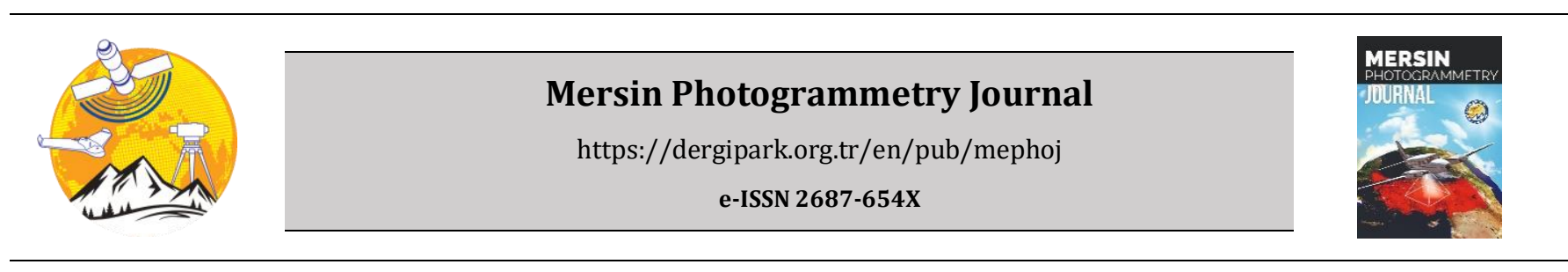

\title{
Three-dimensional modeling and drawings of stone column motifs in Harran Ruins
}

\author{
Yunus Kaya $^{*}{ }^{\oplus}$, Halil İbrahim Şenol1 ${ }^{\oplus}$, Nizar Polat ${ }^{1}$ \\ ${ }_{1}^{1}$ Harran University, Faculty of Engineering, Department of Geomatics Engineering, Sanlıurfa, Turkey
}

\author{
Keywords \\ Archaeology \\ Photogrammetry \\ 3D Model \\ Harran
}

\begin{abstract}
The preservation, documentation, and transmission of archaeological artifacts, which are also defined as heritage, can be accepted as the common responsibility of humanity. To document the cultural heritage, the status of historical artifacts should be known. The photogrammetry technique has been commonly used in the documentation of cultural heritage in parallel with the technological developments recently. In addition to producing map and topographic products, generating three-dimensional models from two-dimensional photographs has brought the photogrammetry method to an important position. For this reason, contributions are made to different disciplines such as archeology. Digital documentation of archaeological artifacts provides serious advantages. In this study, some of the destroyed stone column samples found in Harran Ruins were modeled by using Structure from Motion (SfM) method. At the end of the study the point clouds, digital surface models, orthoimages and stone column motifs were obtained.
\end{abstract}

\section{Introduction}

Historical artifacts are cultural heritages that host hundreds of years of information, and this information should be handed down to the next generations. While these historical heritages reflect the lifestyle and sense of aesthetics of the ancient civilization; they have changed over time due to natural and artificial effects such as wars and earthquakes. Documenting and preserving the natural texture of historical artifacts without damage is an indispensable factor for handing them down to the next generations. It is a fact that cultural heritage is damaged not only in our country but also in many parts of the world. For this reason, the documentation of cultural heritage is among the hot topics all over the world.

Documentation of archaeological artifacts and cultural heritage is a complex process (Kulur and Yllmaztürk, 2005; Ulvi et al., 2020). Documentation of archaeological artifacts consists of the study, process, storage, and presentation steps necessary to determine the current state (shape and location) of the structure in three-dimensional (3D) (Georgopoulos and Ioannidis, 2004). There are several techniques for documenting cultural heritage (Bohler and Heinz, 1999; Şanlıoğlu et al., 2013). Photogrammetry (Kaya et al., 2021; Ulukavak et al., 2019; Polat et al., 2020) and scanning methods (Senol et al., 2017) are at the forefront of these very important and necessary techniques (Bohler and Heinz, 1999; Scherer, 2002; Şenol et al., 2020). At this point, it is a great advantage that photogrammetry can provide reliable information in a short time (Yakar et al., 2011; Şasi and Yakar, 2018).

Today, with the development of photogrammetry and computer vision disciplines, image-based modeling techniques have become a serious competitor to laser scanning (Remondino et al., 2011). Some notable advantages of image-based modeling are it is low cost and contains color information, calibrated or uncalibrated cameras are acceptable (Colomina et al., 2008) and can produce a denser cloud of points than a laser scanner. At this point, unlike classical photogrammetry, the motion-based structural detection (Structure from Motion -SfM) approach is widely used (Polat et al., 2020). SfM operates under the same basic conditions as Photogrammetry. Overlapping images are used to obtain the 3D structure of the object of interest. Many commercial software such as Agisoft 
Photoscan are also widely used for 3D modeling. In general, it allows to produce many products such as matching photos, producing sparse and dense point clouds, three-dimensional model, digital elevation model and orthophoto. Image processing steps can take serious time. For this reason, the use of highperformance computers is especially recommended to produce a full-performance 3D model (Siebert and Teizer, 2014). In this study, three-dimensional models of some of the figures found in the historical Harran Archaeological Site were created digitally by the SfM method and three selected stone column motifs were drawn.

\section{Method}

\subsection{Study area}

The study was carried out at the excavation site in İçkale, Harran Ruins in the Harran district of Şanlıurfa (Figure 1). The wall structures and infrastructure of the Harran region, which is one of the oldest settlements of human civilization, have been built, repaired, enlarged or reduced in a very long time. The Old Harran region, which dates back to $5000 \mathrm{BC}$, is an important city in Upper Mesopotamia. There are many historical artifacts from different civilizations in the region. One of the most important of these is the Harran castle. The parts where active excavation and repair have been completed are open to touristic visits. Archaeological studies have been carried out on the relevant region at different times. Today, with the support of the Ministry of Culture and Tourism, the Turkish Historical Society, Harran University and local support, Prof. Dr. Mehmet ÖNAL and his archeology team carry out archaeological excavations in the Harran Ruins. During the studies carried out in İçkale, the Kale Bath (Önal, 2019; Önal, 2020), the South-East Gate and the rectangular tower and the second defense system in the west of the castle were unearthed. Excavations continue on the remains of the castle bridge. In the study, some of the destroyed stone column motifs samples found in the excavation area of Harran Ruins were modeled in three dimensions and drawn.

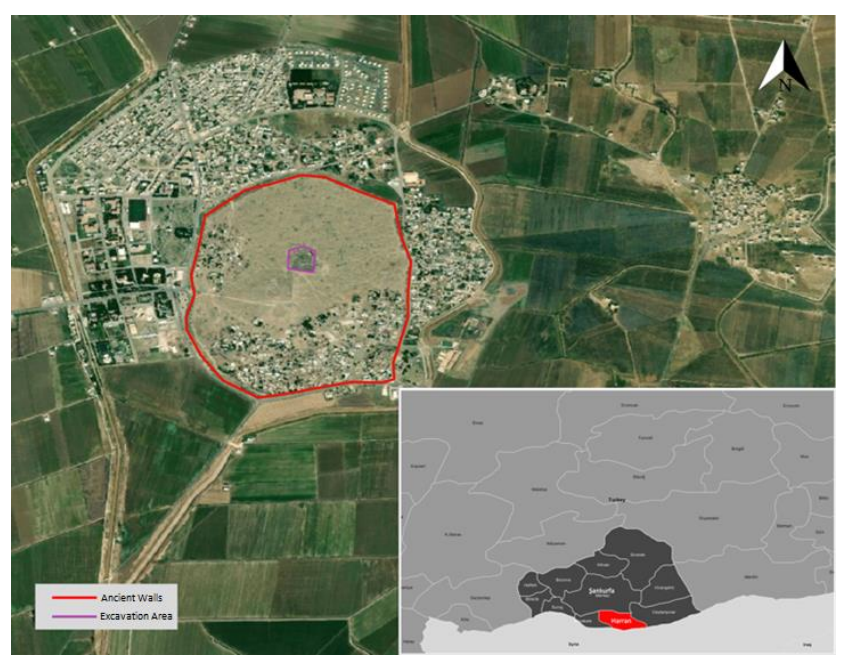

Figure 1. The ancient city of Harran, the excavation site and the location of the town of Harran

\subsection{Equipment}

Embossed figures in the archaeological area have been documented by the SfM. Overlay photographs are required to cover the entire object so that the documentation process can be done precisely. Canon EOS 2000D model DSLR camera was used for this process in the study. Information about the digital camera used is given in Table 1.

Table 1. Technical specifications of the camera used

\begin{tabular}{ll}
\hline Feature & Value \\
\hline Megapixel & 24.1 \\
Maximum resolution & $6000 \times 4000$ \\
Weight & $475 \mathrm{~g}$ \\
Size & $129 \times 101.3 \times 77.6 \mathrm{~mm}$ \\
Sensor size & $22.3 \times 14.9 \mathrm{~mm}$ \\
\hline
\end{tabular}

\subsection{Application}

In the study, dense point cloud and 3D model of three different models were produced with photographs taken from the ground. Terrestrial photogrammetry, which is a useful method for structures no larger than human height, can convert photos taken with simple digital handheld cameras into high-precision 3D models. The stones with figures, which are the subject of the study, are modeled in 3D with the SfM method, which is widely used in the world. Although the SfM approach was developed by the computer vision community to achieve an automatic image matching algorithm, it works under the same basic conditions as Stereoscopic Photogrammetry (Tanskanen et al., 2013; Snavely, 2009; Westoby et al., 2012; Micheletti et al., 2015). Overlapping images are used to obtain the 3D form of the object of interest (Yakar et al. 2005). However, there is a fundamental difference between traditional Photogrammetry and SfM. In traditional Photogrammetry, the 3D position of cameras or the 3D position of ground control points (GCP) must be known to determine the 3D position of points in an image (Yakar et al. 2010). In contrast, SfM automatically determines the geometric parameters (orientation, internal and external parameters) without any known predefined set of GCPs. Instead, these parameters are resolved simultaneously using a highly overlapping image set with the same features automatically mapped (Snavely, 2009). Then, the iterative, non-linear least squares minimization process traces the matching features from image to image, estimating camera positions and object coordinates. Compared to traditional photogrammetry, the camera positions determined are in the image space, meaning there is no scale and no orientation when considering the object area. This is solved by 3D similarity transformation using a small number of ground control points in areas such as map production (Westoby et al., 2012). In object modeling, it is often sufficient to specify a scale. To get a useful 3D geometry of the object, the images must fully cover the object (Yakar et al. 2015). In order to fulfill this condition, it is necessary for the camera to view the object from every angle. 


\section{Results}

In this study, reliefs on 3 historical stones with figures on them were extracted by relief method that found in the archaeological excavation area of the historical Harran Ruins were discussed. The inscription fragments we obtained after the excavation were broken over time and underwent physical changes (Figure 2). In order to document the stones digitally, 3D modeling was carried out with the photogrammetry method. For this purpose, three different stones that were found during the excavations and waiting to be classified were examined as examples (Figure 2).

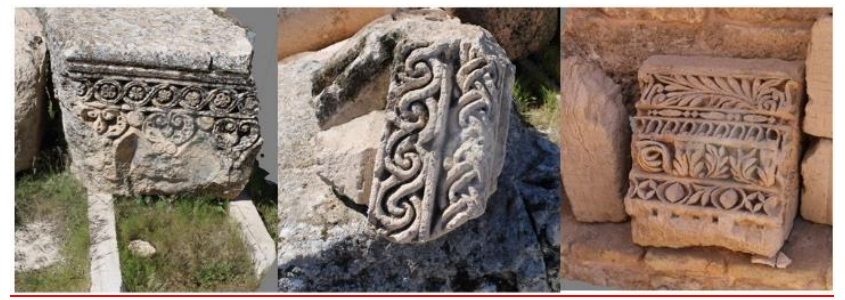

Figure 2. Images of selected stone column motifs
For the three pieces of stones, 38, 52 and 33 photographs were taken locally, respectively. In order to model the figures exactly, photographs of the objects were taken from all angles as much as possible. As the stones were lined up at the bottom of the castle wall, the desired number of photographs could not be obtained by the wall (Figure 3 ).

The number of 3D model triangles also increases and decreases proportionally to the number of point clouds. At least over five million 3D points are produced, modeled with high density. 3D models were obtained from the produced point clouds and photorealistic models were obtained by covering these models with real color texture. To visualize the figures in the models more clearly, only the surface of the models with the inscriptions was taken and the height model of the surface was obtained (Figure 3). Thanks to the height model produced, the legibility of the letters is increased as the embossments formed by the letters are colored differently from the ground. Drawings were made to increase the intelligibility of the patterns. The patterns on the stones were drawn by hand.
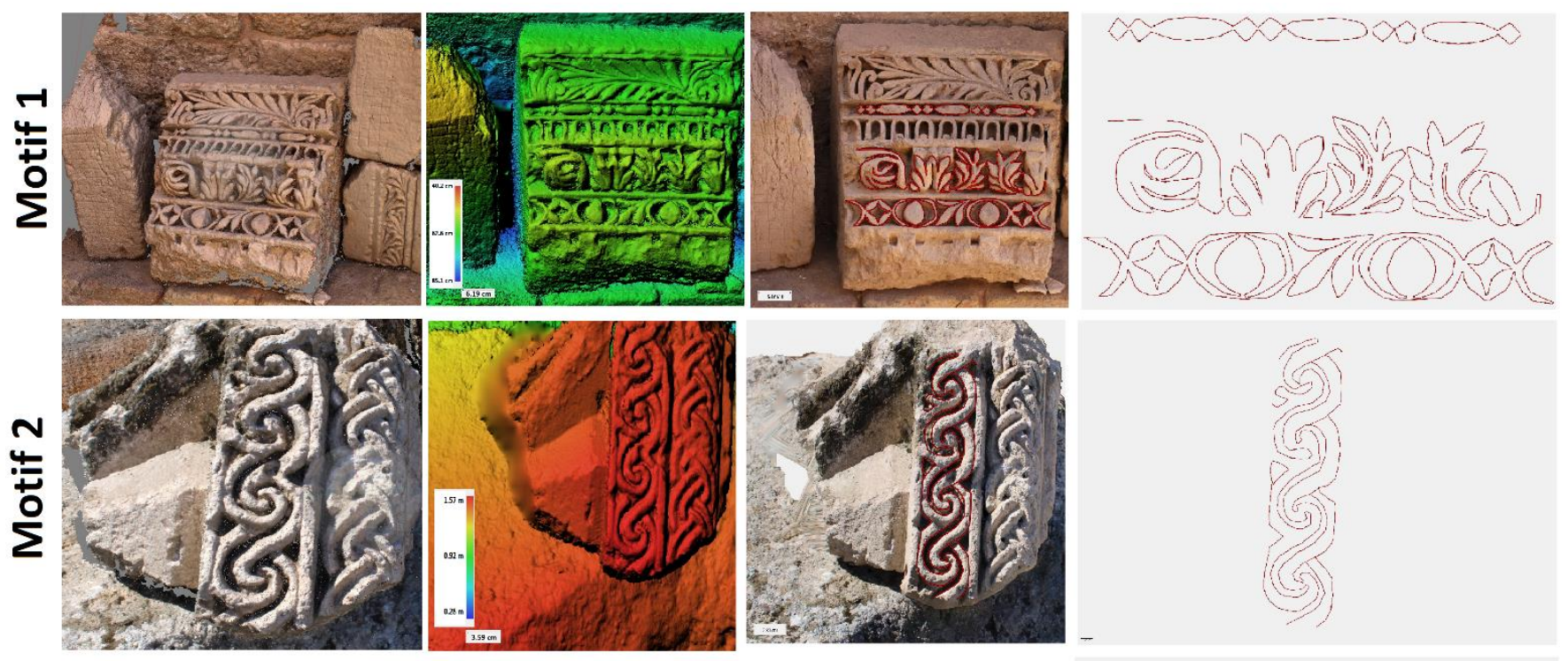

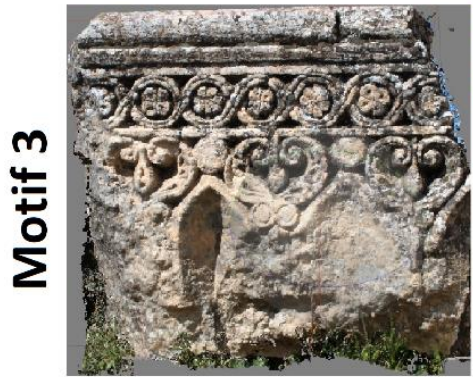

Point Cloud

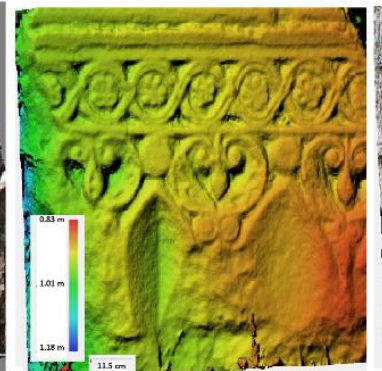

Surface Model

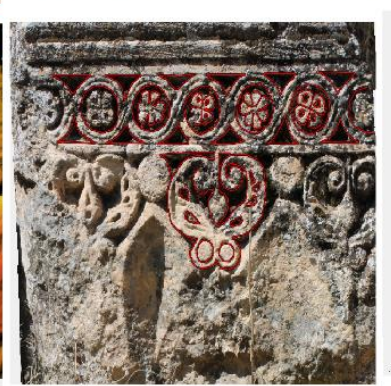

Drawings About the Stones Motifs

Figure 3. Point Cloud, Surface Model, Drawings About the Stone Motifs and Extracted Motifs

\section{Results}

It is very important in terms of protecting and documenting our cultural heritage, which should be transferred to future generations. In this context, the samples selected from the stones found in the Harran archaeological excavation area were modeled by the photogrammetric method. The digital records obtained with the three-dimensional modeling carried out contribute to the creation of digital archives of the 
works. In addition to these, the three-dimensional models obtained can also be used in restoration and restitution studies. Photogrammetric products such as the resulting three-dimensional model and point cloud are also in a position to meet the needs of studies in different disciplines. In the study, three different pieces of stone figures were selected, photographed and processed photogrammetrically. As a result, a threedimensional model and a digital surface model of the stone surface were obtained. The figures that can be seen from the digital surface model were read and recorded. Figured stones damaged by environmental factors such as abrasion, breakage and algae are difficult to seen and perceive with the naked eye. Thanks to the models obtained in 3D by the photogrammetric method, perception and reading convenience are achieved. As a result, the photogrammetric approach offers serious contributions in terms of digital documentation, threedimensional modeling and drawing of stone column motifs. In future studies, all stone motif, patterns, and ornaments found in the Harran ruins are planned to be modeled and documented digitally.

\section{Author contributions}

Yunus Kaya: Visualization, Investigation, WritingOriginal draft preparation. Halil İbrahim Şenol: Visualization, Investigation, Writing-Reviewing, and Editing; Nizar Polat: Data curation, Conceptualization, Software, Validation.

\section{Conflicts of interest}

The authors declare no conflicts of interest.

\section{References}

Bohler W \& Heinz G (1999). Documentation, surveying, photogrammetry. XVII CIPA Symposium. Recife, Olinda.

Colomina I, Blázquez M, Molina P, Parés M E, Wis M (2008). Towards a New Paradigm for HighResolution Low-Cost Photogrammetry and Remote Sensing. IAPRS\&SIS, 1201-1206.

Georgopoulos A \& Ioannidis G (2004). Photogrammetric and Surveying Methods for the Geometric Recording of Archaeological Monuments, Archaeological Surveys. FIG Working Week 2004, May 22- 27, 2004, Athens, Greece.

Kaya Y, Yiğit A Y, Ulvi A \& Yakar M (2021). Arkeolojik Alanların Dokümantasyonununda Fotogrametrik Tekniklerinin Doğruluklarının Karşılaştırmalı Analizi: Konya Yunuslar Örneği. Harita Dergisi, 165: 57-72.

Kulur S \& Yilmazturk F (2005). 3D Reconstruction of Small Historical Objects to Exhibit in Virtual Museum by Means of Digital Photogrammetry. CIPA XX. International Symposium, International Cooperation to Save the World's Cultural Heritage, 26 Sep.-01 Oct., Torino, Italy.
Micheletti N, Chandler J H \& Lane S N (2015). Investigating the geomorphological potential of freely available and accessible structure-frommotion photogrammetry using a smartphone. Earth Surface Processes and Landforms, 40 (4): 473-486.

Önal M (2019). Harran 2017 Yılı Çalışmaları, 40. Kazı Sonuçları Toplantısı. 2. Cilt, Ankara, 632- 650.

Önal M (2020). Harran 2018 Yılı Çalışmaları, 41. Kazı Sonuçları Toplantısı 3. Cilt. Ankara, 157- 180.

Polat N, Önal M, Ernst F B, Şenol H İ, Memduhoğlu A, Mutlu S, Mutlu S İ, Budan M A, Turgut M \& Kara H (2020). Harran Ören Yeri Arkeolojik Kazı Alanınındın Çıkarılan Bazı Küçük Arkeolojik Buluntuların Fotogrametrik Olarak 3B Modellenmesi. Türkiye Fotogrametri Dergisi, 2 (2), 55-59.

Remondino F, Barazzetti L, Nex F, Scaioni M \& Sarazzi D (2011). UAV Photogrammetry for Mapping and 3D Modeling Current Status and Future Perspectives. ISPRS ICWG I/V UAV-g Conference, Zurich, Switzerland.

Scherer M (2002). About the Synthesis of Different Methods in Surveying. XVIII International Symposium of CIPA, Potsdam, Germany.

Senol H I, Erdogan S, Onal M, Ulukavak M, Memduhoglu A, Mutlu S, Ernst F B \& Yilmaz M (2017). 3D Modeling of a Bazaar in Ancient Harran City Using Laser Scanning Technique. International Archives of the Photogrammetry, Remote Sensing \& Spatial Information Sciences, 42.

Siebert S \& Teizer J (2014). Mobile 3D Mapping for Surveying Earthwork Projects Using an Unmanned Aerial Vehicle (UAV) System. Autom. Constr., 41: 114.

Snavely N K (2009). Scene Reconstruction and Visualization From Internet Photo Collections. Doctoral Thesis, University of Washington.

Şanlığlu İ, Zeybek M \& Karauğuz G (2013). Photogrammetric Survey and 3D Modeling of Ivriz Rock Relief in Late Hittite Era. Mediterranean Archaeology and Archaeometry, 13 (2): 147-157.

Şasi A \& Yakar M (2018). Photogrammetric Modelling of Hasbey Dar'ülhuffaz (Masjid) Using an Unmanned Aerial Vehicle. International Journal of Engineering and Geosciences, 3 (1), 6-11.

Şenol H İ, Memduhoglu A \& Ulukavak M (2020). Multi Instrumental Documentation and 3D Modelling of an Archaeological Site: a Case Study in Kizilkoyun Necropolis Area. Dicle Üniversitesi Mühendislik Fakültesi Mühendislik Dergisi, 11 (3): 1241-1250.

Tanskanen P, Kolev K, Meier L, Camposeco F, Saurer 0 \& Pollefeys M (2013). Live Metric 3D Reconstruction on Mobile Phones. in: 2013 IEEE Int. Conf. Comput. Vis., IEEE, 65-72.

Ulukavak M, Memduhoğlu A, Şenol H İ \& Polat N (2019). Excavation Monitoring With UAV in Şanlıurfa Castle Archaeological Site. Mersin Photogrammetry Journal, 1 (1): 23-26.

Ulvi A, Yakar M, Yiğit A Y \& Kaya Y (2020). İHA ve Yersel Fotogrametrik Teknikler Kullanarak Aksaray Kızıl Kilise'nin 3 Boyutlu Nokta Bulutu ve Modelinin Üretilmesi. Geomatik Dergisi, 5 (1), 22-30. 
Westoby M J, Brasington J, Glasser N F, Hambrey M J \& Reynolds J M (2012). StructurefromMotion'photogrammetry: A Low-Cost, Effective Tool for Geoscience Applications. Geomorphology, 179: 300-314.

Yakar M, Yıldız F \& Yılmaz H M (2005). Tarihi ve Kültürel Miraslarin Belgelenmesinde Jeodezi Fotogrametri Mühendislerinin Rolü. TMMOB Harita ve Kadastro Mühendisleri Odası, 10.

Yakar M, Yılmaz H M \& Mutluoğlu Ö (2010). Comparative evaluation of excavation volume by
TLS and total topographic station based methods. Lasers in Eng,19, 331-345.

Yakar M, Yıldız F, Özkütük A, Neșeli O, Kurhan E \& Durdu O (2011). Sultanhanı Kervansarayı Fotogrametrik Rölöve Alımı ve 3 Boyutlu Modelleme Çalışması. 13. Türkiye Harita Bilimsel ve Teknik Kurultayı.

Yakar M, Orhan O, Ulvi A, Yiğit A Y \& Yüzer M M (2015). Sahip Ata Külliyesi Rölöve Örneği. TMMOB Harita ve Kadastro Mühendisleri Odası, 10. 